\title{
Kepemimpinan Pendidikan Prespektif Managemen Mutu Terpadu \\ KEPEMIMPINAN PENDIDIKAN \\ PERSPEKTIF MANAGEMEN MUTU TERPADU \\ (Sebagai Upaya Regulasi Mutu Lembaga Pendidikan)
}

\author{
Nanang Budianto \\ Dosen Tetap Yayasan Institut Agama Islam Al Falah As Sunniyyah \\ Kencong Jember \\ penembahanujungkulon@gmail.com
}

\begin{abstract}
Leadership leadership must be able to influence, move, guide and maintain people's activities so that organizational goals can be achieved. As expressed by Sudarwan Danim, leadership is the energy that influences and gives direction which is contained in the leader's personal self. Or leadership is energy that can move, guide and maintain people's activities so that organizational goals can be achieved. The same thing was expressed by Owens, leadership is an interaction between one party as the leader with the party led.
\end{abstract}

\section{Keyword : Leadership, Education, Integrated Quality Management}

\section{PENDAHULUAN}

Dalam suatu organisasi baik yang bergerak dalam bidang pendidikan, sosial - kemasyarakatan, perindustrian, pertanian, perdagangan, dll dibutuhkan seorang pemimpin untuk memimpin organisasi tersebut, Karena pemimpin diibaratkan seorang sopir untuk menentukan jalannya suatu organisasi.

Kepemimpinan seorang pemimpin harus bisa mempengaruhi, menggerakkan, membimbing dan menjaga aktivitas orang sehingga tujuan organisasi dapat tercapai. Sebagaimana yang diungkapkan oleh Sudarwan Danim kepemimpinan merupakan energi mempengaruhi dan memberi arah yang terkandung didalam diri pribadi pemimpin. ${ }^{1}$ Atau kepemimpinan merupakan energi yang dapat menggerakkan, menuntun dan menjaga aktivitas orang sehingga tujuan organisasi dapat tercapai. ${ }^{2}$ Hal senada diungkapkan Owens,

${ }^{1}$ Sudarwan Danim dan Suparno, Manajemen Dan KepemimpinanTransformasional Kekepalasekolahan, Jakarta : Reneka Cipta, 2009, 41.

${ }^{2}$ Ibid, 41 . 
kepemimpinan merupakan suatu interaksi antara satu pihak sebagai yang memimpin dengan pihak yang dipimpin. ${ }^{3}$

Keberagaman masyarakat ( yang dipimpin ) dibutuhkan keahlian khusus bagi seorang pemimpin untuk mengoptimalkan sumber daya yang ada untuk mencapai tujuan organisasi, dikarkanakan sebaik apapun konsep yang dimiliki organisasi tanpa di sertai dengan keterampilan seorang pemimpin maka produk yang dihasilkan tidak dapat maksimal.

Keahlian khusus yang harus dimiliki seorang pemimpin salah satunya adalah mempunyai pemikiran yang strategis, diantaranya :

1. Fokus pada jangka panjang

2. Kreativitas

3. Membaca atau mengamati lingkungan eksternal

4. Mengadopsi sebuah pandangan menyeluruh. ${ }^{4}$

Disamping keahlian khusus, seorang pemimpin harus memliki komitmen untuk peningkatan mutu secara terus menerus terhadap organisasi yang dipimpinnya, Sehingga produk yang dihasilkan sesuai kebutuhan pelanggan. West-Burnham mengatakan mutu terpadu adalah sebuah filosofi dengan alat-alat dan proses-proses implementasi praktis yang ditujukan untuk mencapai sebuah kultur perbaikan terus-menerus yang digerakkan oleh semua pekerja sebuah organisasi, dalam rangka memuaskan pelanggan. ${ }^{5}$

Dari uraian diatas dapat dipahami bahwa seorang pemimpin harus mempunyai kompetensi terhadap kepemimpinannya dalam memimpin sebuah organisasi dan tentunya mempunyai komitmen yang kuat dalam peningkatan mutu secara terus menerus sehingga produk yang dihasilkan dapat memenuhi kebutuhan pelanggan.

Dalam tulisan ini akan membahas 3 (tiga) hal penting dalam kepemimpinan pendidikan perspektif managemen mutu terpadu : pertama, Bagaimana konsep dasar kepemimpinan pendidikan dan managemen mutu terpadu?, kedua : Bagaimana kepemimpinan pendidikan perspektif managemen mutu terpadu?, ketiga : Bagaimana implementasi managemen mutu terpadu terhadap kepemimpinan pendidikan?

${ }^{3}$ Owens, Ibid, 41.

4 Tony Bush dan Marianne Colemen, Manajemen Strategis Kepemimpinan Pendidikan, Jogjakarta : IRCiSoD, 2008, 32

${ }^{5}$ West-Burnham dalam Tony Bush dan Marianne Colemen, Manajemen Strategis Kepemimpinan Pendidikan, Jogjakarta : IRCiSoD, 2008, 190-191.

146 | FaLASIFA, Vol. 9 Nomor 1 Maret 2018 


\section{PEMBAHASAN}

\section{Konsep dasar kepemimpinan pendidikan dan managemen mutu terpadu}

Kepemimpinan adalah proses mempengaruhi dalam menentukan tujuan organisasi, memotivasi prilaku pengikut untuk mencapai tujuan, mempengaruhi untuk memperbaiki kelompok dan budayanya. ${ }^{6}$ Secara khusus Gary Yukl menyatakan bahwa, memahami kepemimpinan sebagai sebuah proses mempengaruhi dalam suatu kelompok untuk mencapai tujuan orang bersama. ${ }^{7}$ Kepemimpinan adalah kemampuan untuk mempengaruhi suatu kelompok kerah tercapainya tujuan. $^{8}$

Dapat diambil kesimpulan, kepemimpinan merupakan proses mempengaruhi anggota organisasi yang dilakukan oleh seorang pemimpin untuk mencapai tujuan organisasi. Hal tersebut juga memberi penjelasan bahwa kepemimpinan merupakan proses-proses mempengaruhi, memotivasi, pengorganisasian aktivitas tersebut untuk mencapai sasaran. Motivasi dari para pengikut untuk mencapai sasaran, pemeliharaan hubungan kerjasama dengan teamwork untuk mencapai sasaran dan tujuan organisasi. Hal ini dapat dipahami bahwa kepemimpinan mencakup hubugan pemimpin dengan anggota organisasi untuk mencapai tujuan yang telah ditetapkan.

a. Karakteristik kepemimpinan

Rivai, menjelaskan beberapa perbedaan antara pemimpin dan manajer :

1) Pemimpin tidak selalu berada dalam sebuah organisasi, sedangkan manajer selalu dalam organisasi tertentu baik formal maupun non formal.

2) Pemimpin bisa ditunjuk atau diangkat oleh anggotanya, sedangkan manajer selalu ditunjuk.

3) Pengaruh yang dimiliki pemimpin, karena memiliki kemampuan pribadi yang lebih dibandingkan dengan yang lain, sedangkan pengaruh yang dimiliki manajer karena dimilikinya otoritas formal.

4) Pemimpin memikirkan organisasi secara luas dan jangka panjang, sedangkan manajer berfikir jangka pendek dan sebatas tugas dan tanggungjawabnya.

5) Pemimpin memiliki keterampilan politik dalam menyelesaikan politik dalam menyelesaikan konflik, sementara manajer menggunakan pendekatan formal-legal.

${ }^{6}$ Mulyadi, Kepemimpinan Kepala Sekolah Dalam Mengembangkan Budaya Mutu, Malang : UIN-MALIKI PREES, 2010, 1.

${ }^{7} \mathrm{Ibid}, \mathrm{I}$.

${ }^{8}$ Stephen P. Robbins, Prilaku Organisasi, Jakarta : PT.Prenhallindo, 2002, 3.

FaLASIFA, Vol. 9 Nomor 1 Maret 2018 | 147 
Nanang Budianto

6) Pemimpin berfikir untuk kemajuan dan perbaikan organisasi secara luas, sementara manajer berfikir untuk kepentingan diri dan kelompok secara sempit.

7) Pemimpin memiliki kekuasaan secara luas, sedangkan manajer hanya memiliki wewenang saja. ${ }^{9}$

Kepemimpinan efektif berdasar beberapa penelitian harus menyesuaikan dengan tugas kelompok, organisasi-organisasi dalam tugas kelompok dan situasi organisasi. Hoy dan Miskel memberi batasan 4 ( empat) komponen kepemimpinan : melibatkan orang lain, mendistribusikan kekuasaan, kemampuan menggunakan berbagai bentuk kekuasaan untuk mempengaruhi organasasi lain atau pengikut, nilai yaitu mencakup semua sistem yang dapat menciptakan prilaku yang dipimpin. ${ }^{10}$

Lebih lanjut Benis dan Nanus mengungkapkan kepemimpinan efektif mempunyai beberapa kompetensi : (1) Manajemen : pemimpin mampu memahami tujuan lembaga dan dapat mengelola simbol-simbol organisasi untuk tujuan, (2) perhatian : kemampuan pemimpin mengajak para staf mengarahkan perhatian tenaga dan bakat untuk mencapai tujuan lembaga, (3) manajemen kepercayaan : berupaya menumbuhkan kepercayaan orang lain, (4) para staf dan menerapkan gaya kepemimpinan kondisional manajemen diri : pemimpin mengenal dan memahami dirinya. ${ }^{11}$

b. Gaya Dan Tipe Kepemimpinan

1) Gaya kepemimpinan

Gaya kepemimpinan adalah sekumpulan ciri yang gunakan pimpinan untuk mempengaruhi bawahan agar sarana organisasi tercapai atau dapat pula dikatakan gaya kepemimpinan adalah pola prilaku dan strategi yang disukai dan sering diterapkan pemimpin. ${ }^{12}$

Seoramg pemimpin yang efektif harus menggunakan gaya kepemimpinan yang berbeda dalam situasi yang berbeda, jadi tidak bergantung pada satu pendekatan untuk semua situasi.

2) Tipe Kepemimpinan

Adapun tipe-tipe kepemimpinan yang harus diketahui :

${ }^{9}$ Mulyadi, Kepemimpinan Kepala Sekolah Dalam Mengembangkan Budaya Mutu, Malang : UIN-MALIKI PREES, 2010, 8-9.

${ }^{10}$ Hoy dan Miskel, Ibid, 9

${ }^{11}$ Benis dan Nanus, Ibid, 9.

${ }^{12}$ Mulyadi, Kepemimpinan Kepala Sekolah Dalam Mengembangkan Budaya Mutu, Malang : UIN-MALIKI PREES, 2010, 41.

148 | ҒaLASIFA, Vol. 9 Nomor 1 Maret 2018 
Kepemimpinan Pendidikan Prespektif Managemen Mutu Terpadu

a) Pemimpin otoriter

Pemimpin otoriter berasumsi bahwa maju mundurnya organisasi organisasi hanya tergantung pada dirinya. Gaya kepemimpinan otoriter memiliki ciri-ciri antara lain :

(1) Beban kerja organisasi pada umumnya ditanggung oleh pimpinan.

(2) Konsep atau ide-ide baru berasal dari pimpinan, dan bawahan sebagai pelaksana.

(3) Disiplin tinggi, bekerja keras, dan tidak kenal lelah.

(4) Kebijakan ditentukan oleh pemimpin sendiri dan kalau ada musyawarah sifatnya pemberitahuan/sosialisasi.

(5) Kepercayaan pimpinan terhadap bawahan rendah.

(6) Komunikasi dilakukan satu arah dan tertutup.

(7) Koreksi dan minta penyelesaian tugas tepat waktu. ${ }^{13}$

b) Pemimpin Demokratis

Untuk tipe kepemimpinan demokratis, pemimpin memberi kesempatan sebesar-besarnya untuk mengutarakan konsep-konsep atau ide-ide yang dimiliki anggota untuk kemajuan organisasi.

Tipe kepemimpinan demokratis bercirikan sebagai berikut :Beban kerja organisasi menjadi tanggung jawab seluruh personalia.

(1) Bawahan, oleh pimpinan dianggap sebagai komponen pelaksanadan secara integral harus diberi tugas dan tanggung jawab.

(2) Disiplin, tetapi tidak kaku dan memecahkan masalah-masalah secara teratur.

(3) Kepercayaan tinggi terhadap bawahan dengan tidak melepaskan tanggung jawab pengawasan.

(4) Komunikasi dengan bawahan bersifat terbuka dan dua arah. ${ }^{14}$

c) Pemimpin Karismatik

Merupakan suatu pengembangan dari teori atribusi. Para pengikut membuat atribusi dari kemampuan kepemimpinan yang heroik atau luar biasa bila mereka mengamati prilaku-prilaku tertentu. ${ }^{15}$

Terlepas dari pembahasan kepemimpinan, managemen mutu terpadu (TQM) merupakan usaha menciptakan sebuah kultur mutu, yang mendorong

\footnotetext{
${ }^{13}$ Ibid, 45.

${ }^{14}$ Ibid, 46

15 Stephen P. Robbins, Prilaku Organisasi, Jakarta : PT.Prenhallindo, 2002, 25.
}

FaLASIFA, Vol. 9 Nomor 1 Maret 2018 | 149 
Nanang Budianto

semua stafnya untuk memuaskan pelanggannya dan melakukan perbaikan secara terus menerus. ${ }^{16}$

Pada hakikatnya pemimpin adalah seorang yang mempunyai kemampuan untuk mempengarui prilaku orang lain di dalam kerjanya dengan menggunakan kekuasaanya. ${ }^{17}$ Kekuasaan adalah kemampuan untuk mengarahkan dan mempengarui bawahan sehubungan dengan tugas-tugas yang harus di laksanakannya. ${ }^{18}$ Menurut Stoner, semakin banyak jumlah sumber kekuasaan yang tersedia bagi pemimpin, akan makin besar potensi kepemimpinan yang efektif. ${ }^{19}$

Kajian-kajian kepemimpinan sekitar tahun 1960 an telah berkembang. Di kalangan para ilmuan prilaku yang secara khusus mendalami dan cenderung memahami kepemimpinan dalam konteks prilaku pemimpin yang otoriter. Kecenderungan, untuk memahami kepemimpinan secara organik kepemimpinan seperti mekanisme dalam mempengaruhi anggota organisasi di syaratkan dalam sistem birokrasi ketat dan kaku, sehingga penekanan kepemimpinan selalu berada pada sikap pemimpin yang otoriter dan mengabaikan sisi sosial budaya dari organisasi, mengabaikan budaya yang tidak tampak. Dari sini lahir pemahaman bahwa seorang pemimpin yang kuat di perlukan dalam birokrasi yang ketat dan kaku.

Dewasa ini pengertian kepemipinan dalam sejumlah kajian memiliki nuansa sosial budaya yang lebih kuat. Hal ini di dasari penciteraan sosiologisterhadap organisasi sehingga di lihat dari sistem sosial yang memiliki dimensi sosial budaya. Kepemimpinan tidak lagi di pahami secra organik tetapi merupakan dimensi organisasi yang mempunyai kontribusi untuk membangun budaya organisasi yang sehat.

Berdasar uraian di atas dapat di identifikasi beberapa komponen dalam kepemimpinan yaitu: (1) Adanya pemipin dan orang lain yang di pimpin, (2) Adanya upaya atau proses mempengaruhi dari pemimpin kepada orang lain melalui berbagai kekuatan, (3) Adanya tujuan akhir yang ingin di capai bersama dengan adanya kepemimpinan itu, (4) Kepemimpinan bisa timbul dalam suatu organisasi atau tanpa adanya organisasi tertentu, (5) Pemimpin dapat di angkat 2010, 59 .

${ }^{16}$ Edward Sallis, Total Quality Management In Education, Jogjakarta : IRCiSoD,

${ }^{17}$ Jamal Ma'mur Asmani, Managemen Pengelolaan dan Kepemimpinan Pendidikan Profesional Panduan Quality Kontrol Bagi Para Pelaku Lembaga Pendidikan, (Yogyakarta : Diva Pres, 2009) hlm 92
${ }^{18}$ Ibid, 92
${ }^{19} \mathrm{Ibid}, 92$

150 | FaLASIFA, Vol. 9 Nomor 1 Maret 2018 
secara formal atau di pilih oleh pengikutnya, (6) Kepemimpinan berada dalam situasi tertentu baik situasi pengikut maupun lingkungan eksternal.

\section{Karakteristik Pemimpin}

Kepemimpinan merupakan seni untuk mempengarui aktivitas individu atau kelompok secara sengaja untuk mencapai tujuan organisasi. ${ }^{20}$ Di lihat dari sisi ini unsur utama dari kepemimpinan adanya hubungan mempengarui antara pimpinan dengan anak buah, atasan dengan bawahan untuk melaksanakan tugastugas organisasi. Tujuan akhir dari tugas kepemimpinan mengoptimalkan semua potensi organisasi agar tercipta kinerja organisai yang sehat sehingga tujuan tercapai secara efektif dan efisien.

Rivai menjelaskan beberapa perbedaan antara pemimpin dengan manajer sebagai berikut : (1) Pemimpin tidak selalu berada dalam sebuah organisasi, sedangkan manajer selalu dalam organisasi baik itu formal maupun non formal, (2) Pemimpin bisa ditunjuk atau diangkat oleh anggotanya, sedangkan manajer selalu ditunjuk, (3) Pengaruh yang dimliki pemimpin, karena memiliki kemampuan pribadi yang lebih dibandingkan dengan yang lain, sedangkan pengaruh yang dimiliki manajer karena dimilikinya otoritas formal, (4) Pemimpin memikirkan organisasi secara lebuh luas dan jangka panjang, sedangkan manajer berfikir jangka pendek dan sebatas tugas dan tanggung jawabnya, (5) Pemimpin memiliki keterampilan politik dalam menyelesaikan konflik, sementara manajer menggunakan pendekatan formal-legal, (6) Pemimpin berfikir untuk kemajuan dan perbaikan organisasi secara luas sementara manajer berfikir untuk kepentingan diri dan kelompoknya secara sempit, (7) Pemimpin memiliki kekuasaan secara lebih luas, sedangkan manajer hanya memiliki wewenang saja. ${ }^{21}$

Kepemimpinan efektif berdasar beberapa penelitian harus menyesuaikan dengan tugas kelompok dan situasi organisasi. Dengan kata lain kepemimpinan akan menjadi efektif apabila disesuaikan dengan situasi dan kondisi yang tepat. Hoy dan Miskel memberi batasan 4 (empat) komponen kepemimpinan melibatkan orang lain, mendistribusikan kekuasaan, kemampuan menggunakan berbagai bentuk kekuasaan untuk mempengaruhi organisasi lain atau pengikut, nilai yaitu menyakup semua sistem yang dapat menciptakan prilaku yang dipimpin. ${ }^{22}$

${ }^{20}$ Mulyadi, Kepemimpinan Kepala Sekolah Dalam Mengembangkan Budya Mutu, (Malang : UIN Maliki Press, 2010) hlm 8.

${ }^{21}$ Rivai (2006) dalam Mulyadi, Ibid 8

${ }^{22}$ Mulyadi, Kepemimpinan Kepala Sekolah Dalam Mengembangkan Budya Mutu, (Malang : UIN Maliki Press, 2010) hlm 9 
Disisi lain Sergiovanni mengidentifikasi 5 (lima) kekuatan kepemimpinan diantaranya : (1) Kekuatan teknis, pemimpin sebagai penggerak manusia, (2) Kekuatan manusia, pemimpin sebagai penggerak manusia, (3) Kekuatan simbolik, memfikuskan pada hal-hal yang penting, pemimpin sebagai ketua, (4) Kekuatan kultur, pemimpin sebagai tokoh spiritual. ${ }^{23}$

\section{Tipe Tipe Kepemimpinan}

Menurut G. R. Terry sebagaimana disitir Maman Ukas, ada 6 (enam) tipe :

a. Tipe kepemimpinan pribadi (personal leadership)

Dalam sistem kepemimpinan ini, segala sesuatu tindakan itu dilakukan dengan mengadakan kontak pribadi. Petunjuk itu dilakukan secara lisan atau langsung dilakukan secara pribadi oleh pemimpin yang bersangkutan.

b. Tipe kepemimpinan non pribadi (non personal leadership) Segala sesuatu kebijaksanaan dilaksanaan melalui bawahan-bawahan atau non pribadi baik rencana atau perintah juga pengawasan.

c. Tipe kepemimpinan otoriter (authoritarian leadership) Pemimpin otoriter biasanya bekerja keras, sungguh-sungguh, teliti, dan tertib. Ia bekerja menurut peraturan-peraturan yang berlaku secara ketat dan instruksi-instruksi harus ditaati.

d. Tipe kepemimpinan demokratis (democratic leadership) Kepemimpinan demokratis menganggap dirinya sebagai bagian dari kelompoknya dan bersama-sama dengan kelompoknya berusaha bertanggung jawab atas terlaksananya tujuan bersama.

e. Tipe kepemimpinan paternalistik (paternalistic leadership)

Kepemimpinan ini dicirikan oleh suatu pengaruh yang bersifat kebapakan dalam hubungan pemimpin dan kelompok. Tujuannya untuk melindungi dan memberikan arah seperti halnya bapak kepada anaknya.

f. Tipe kepemimpinan menurut bakat (indigenous leadership)

Kepemimpinan tipe ini timbul dari kelompok orang-orang informal, dimana mereka berlatih dengan adanya sitem kompetisi, sehingga bisa menimbulkan klik-klik dari kelompok yang bersangkutan. ${ }^{24}$

Sedangkan menurut Kurt Lewis, tipe-tipe kepemimpinan ada 3 (tiga), yaitu:

${ }^{23}$ Sergiovanni (1984) dalam Tony Bush dan Marienne Coleman, Manajemen Strategis Kepemimpinan Pendidikan, (Yogyakarta : IRCiSoD, 2008), hlm 67

${ }^{24}$ Jamal Ma'mur Asmani, Managemen Pengelolaan dan Kepemimpinan Pendidikan Profesional Panduan Quality Kontrol Bagi Para Pelaku Lembaga Pendidikan, (Yogyakarta : Diva Pres, 2009), hlm 100-101 
1. Otokratis, yaitu pemimpin yang bekerja keras, sungguh-sungguh, teliti, dan tertib. Ia bekerja menurut peraturan yang berlaku dengan ketat dan instruksiinstruksinya harus ditaati.

2. Demokratis, yaitu Kepemimpinan demokratis menganggap dirinya sebagai bagian dari kelompoknya dan bersama-sama dengan kelompoknya berusaha bertanggung jawab atas terlaksananya tujuan bersama.

3. Laissez-faire, yaitu pemimpin yang menyerahkan sepenuhnya pada para bawahannya untuk mengerjakan pekerjaan-pekerjaan yang menjadi tanggung jawabnya, setelah tujuan diterangkan kepadanya. ${ }^{25}$

Adapun peran yang harus dilakukan seorang pemimpin sebagaimana dikemukakan oleh M.Ngalim Purwanto adalah sebagai berikut :

1. Sebagai pelaksana (executive)

2. Sebagai perencana (planner)

3. Sebagai seorang ahli (expert)

4. Sebagai wakil kelompok dalam tindakannya keluar (external group representative)

5. Sebagi pengawas hubungan antar anggota-anggota kelompok (controller of internal relationship)

6. Bertindak sebagai pemberi gambaran/pujian atau hukuman (purveyor of rewards and punishments)

7. Bertindak sebagai wasit dan penengah (arbritator and mediator)

8. Merupakan bagian dari kelompok (exemplar)

9. Merupakan lambang daripada kelompok (symbol of the group)

10. Pemegang penanggung jawab para anggota kelompoknya (surrogate for individual responsibility)

11. Sebagai pencipta atau pemilik cita-cita (ideologist)

12. Bertindak sebagai seorang ayah (father figur)

13. Sebagai kambing hitam (scepegoat). ${ }^{26}$

\section{Prilaku Kepemimpinan}

Prilaku kepemimpinan merupakan tindakan-tindakan spesifik seorang dalam mengarahkan dan mengkoordinasikan kerja anggota kelompok. ${ }^{27}$ Menurut

\footnotetext{
${ }^{25}$ Ibid, hlm 102

${ }^{26}$ Ibid, hlm 104-105

27 Mulyadi, Kepemimpinan Kepala Sekolah Dalam Mengembangkan Budya Mutu,
} (Malang : UIN Maliki Press, 2010) hlm 47

FALASIFA, Vol. 9 Nomor 1 Maret 2018 | 153 
pendapat Hasibuan Malayu, bahwa prilaku kepemimpinan dalam melaksanakan tugas-tugas kepemimpinan meliputi aktivitas sebagai berikut :

a. Mengambil keputusan

b. Mengembangkan imajinasi

c. Mengembangkan kesetiaan pengikutnya

d. Pemrakarsa, penggiatan, dan pengendaian rencana

e. Memanfaatkan sumber daya manusia dan sumber-sumber lainnya

f. Melaksanakan kontrol dan perbaikan-perbaikan atas kesalahan

g. Memberikan tanda penghargaan

h. Mendelegasikan wewenang kepada bawahannya

i. Pelaksanaan keputusan dengan memberikan dorongan. ${ }^{28}$

Sementara Gary Yulk mengidentifikasi empat belas prilaku kepemiminan yang dikenal dengan taksonomi manajerial sebagai berikut :

a. Merencanakan dan mengorganisasi (planning and organizing)

b. Pemecahan masalah (problem solving)

c. Menjelaskan peran dan sasaran (clarifying roles and objectifies)

d. Memberi informasi (informing)

e. Memantau (monitoring)

f. Memotivasi dan memberi inpirasi (motivating and inspiring)

g. Berkonsultasi (consulting)

h. Mendelegasikan (delegating)

i. Memberikan dukungan (supporting)

j. Mengembangkan dan membimbing (developing and mentoring)

k. Mengelola konflik dan tim (managing and team building)

1. Membangun jaringan kerja (networking)

m. Pengakuan (recognizing)

n. Memberi imbalan (rewarding). ${ }^{29}$

Dapat diambil benang merah seorang pemimpin harus memiliki kompetensi baik internal maupun eksternal sehingga kinerjanya dapat bermutu.

\section{Kepemimpinan pendidikan perspektif managemen mutu terpadu}

Mutu merupakan suatu kegiatan yang harus dilakukan dan dicapai oleh suatu organisasi agar organisasi tersebut memiliki komitmen untuk tetap eksis sesuai tuntutan zaman dan yang paling mendasar sesuai kebutuhan pelanggan. Hal tersebut sesuai yang diungkapkan oleh Tony Bush dan Marianne Colemen, mutu

\footnotetext{
${ }^{28} \mathrm{Ibid}, \mathrm{h} \operatorname{lm} 47-48$

${ }^{29} \mathrm{Ibid}, \mathrm{hlm} 48-50$
} 
merupakan pemenuhan terhadap kebutuhan pelanngan, bukan kebaikan intrisik. ${ }^{30}$ Atau mutu terpadu adalah sebuah filosofi dengan alat-alat dan proses-proses implementasi praktis yang ditujukan untuk mencapai sebuah kultur perbaikan terus menerus yang digerakkan oleh semua pekerja sebuah organisasi dalam rangka memuaskan pelanggan. ${ }^{31}$

Hal tersebut dapat terealisasi dengan baik kalau pemimpin dan anggota organisasi mempunyai komitmen untuk menciptakan mutu. Implikasi utama yang harus diperhatikan dalam budaya mutu adalah :

a. Penekanan pada totalitas-berlaku untuk semua pekerja.

b. Terdapat pemahaman bersama tentang nilai-nilai dan implikasinya pada kepemimpinan dan tipe manajemen.

c. Terdapat sebuah proses perencanaan yang mengantarkan pada implementasi praktis.

d. Alat-alat dan proses-proses yang mencakup pengawasan dan evaluasi, yang lebih menekankan pada pencegahan dari pada inspeksi.

e. Perhatian diberikan pada pelanggan dari pada kebutuhan penyedia layanan. ${ }^{32}$

Tujuan utama TQM dalam pendidikan adalah meningkatkan mutu pendidikan secara berkelanjutan, terus menerus, dan terpadu. ${ }^{33}$ Adapun prinsip TQM adalah : (1) menfokuskan pada pengguna/pelanggan (costomer focus), (2) peningkatan kualitas pada proses (proces improvement), (3) melibatkan semua komponen pendidikan (total involvement)

Ada 14 (empat belas) konsep mutu yang ditawarkan oleh Deming, diantarnya :

a. Ciptakan sebuah usaha peningkatan produk dan jasa ( memenuhi keb.pelanggan )

b. Adopsi falsafah baru

c. Hindari ketergantungan pd inspeksi massa utk mencapai mutu

d. Akhiri praktek menghargai bisnis dng harga

e. Tingkatkan scr konstan sistem produksi dan jasa

f. Lembagakan pelatihan kerja

g. Lembagakan kepemimpinan

h. Hilangkan rasa takut, agar setiap org bekerja scr efektif

30 Tony Bush dan Marianne Colemen, Management Strategis Kepemimpinan Pendidikan, Jogjakarta : IRCiSoD, 2008, 191.

${ }^{31}$ West-Burnham, 1995, 13, dalam Ibid, 192.

${ }^{32}$ Ibid, 192.

${ }^{33}$ Marno dan Triyo Suprayitno, Managemen dan Kepemimpinan Pendidikan Islam, Bandung : PT. Refika Aditama, 2008, 112.

FalASIFA, Vol. 9 Nomor 1 Maret 2018 | 155 
Nanang Budianto

i. Uraikan kendala2 antar departemen

j. Hapuskan slogan, desakan, dan target serta tingkatkan produktivitas tanpa menambah beban kerja

k. Hapuskan standar kerja yg menggunakan quota numerik

1. Hilangkan kendala2 yg merampas kebanggaan karyawan atas keahliannya

m. Lembagakan aneka program yg meningkatkan semangat dan peningkatan kualitas kerja

n. Tempatkan setiap org dlm tim kerja agar dpt melakukan transformasi. ${ }^{34}$

Salah satu faktor yang menentukan keberhasilan dalam suatu organisasi adalah pemimpin, sehingga tidak dapat dipungkiri seoarang pemimpin harus mempunyai dan menguasai berbagai hal terkait dengan kepemimpinan. Adapun kepemimpinan pendidikan yang ideal perspektif Managemen Mutu Terpadu (MMT/TQM) adalah sebagai berikut :

a. Memiliki visi mutu terpadu bagi institusi.

b. Memiliki komitmen yang jelas terhadap proses peningkatan mutu.

c. Mengkomunikasikan pesan mutu.

d. Memastikan kebutuhan pelanggan menjadi pusat kebijakan dan praktek institusi.

e. Mengarahkan perkembangan karyawan.

f. Berhati-hati dengan tidak menyalahkan orang lain saat persoalan muncul tanpa bukti-bukti yang nyata.

g. Memimpin inovasi dalam institusi.

h. Mampu memastikan bahwa struktur organisasi secara jelas telah mendefinisikan tanggung jawab dan mampu mempersiapkan delegasi yang tepat.

i. Memiliki komitmen untuk menghilangkan rintangan, baik yang bersifat organisasi maupun kulural.

j. Membangun tim yang efektif

k. Megembangkan mekanisme yang tepat untuk mengawasi dan mengevaluasi kesuksesan. ${ }^{35}$ berikut :

Kepemimpinan yang ideal perspektif MMT/TQM yang lain adalah sebagai

a. Pimpinan mendasarkan keputusan pada data, bukan hanya pendapat saja.

b. Pimpinan merupakan pelatih, dan fasilitator bagi setiap individu/bawahan.

${ }^{34}$ Deming dalam Edward Sallis, Total Quality Management In Education, Jogjakarta : IRCiSoD, 2010, 100-103.

${ }^{35}$ Ibid, 173-174.

156 | FaLASIFA, Vol. 9 Nomor 1 Maret 2018 
c. Pimpinan harus secara aktif terlibat dalam pemecahan masalah yang dihadapi oleh bawahan.

d. Pimpinan harus bisa membangun komitmen, yang menjamin bahwa setiap orang memahami misi, visi, nilai dan target perusahaan yang jelas.

e. Pimpinan dapat membangun dan memelihara kepercayaan

f. Pimpinan harus paham betul untuk mengucapkan terima kasih kepada bawahan yang berhasil/berjasa

g. Aktif mengadakan kaderisasi melalui pendidikan dan pelatihan yang terprogram

h. Berorientasi selalu pada pelanggan internal/eksternal

i. Pandai menilai situasi dan kemampuan orang lain secara tepat

j. Dapat menciptakan suasana kerja yang sangat menyenangkan

k. Mau mendengar dan menyadari kesalahan

1. Selalu berusaha memperbaiki system dan banyak berimprovisasi

m. Bersedia belajar kapan saja dan di mana saja. ${ }^{36}$

\section{implementasi managemen mutu terpadu terhadap kepemimpinan pendidikan}

Perbaikan mutu berkesinambungan adalah ciri manajemen pengendalian mutu. Oleh karena itu, untuk membudayakan budaya mutu dalam dunia pendidikan khususnya pimpinan dituntut untuk terus mengadakan perbaikan mutu pendidikan secara berkelanjutan atau berkesinambungan. Model Deming dalam proses perbaikan mutu, diantaranya :

a. Mengadakan riset pelanggan dan menggunakan hasilnya untuk perencanaan produk pendidikan ( Plan).

b. Menghasilkan produk pendidikan melalui proses pembelajaran ( $D o)$.

c. Memeriksa produk pendidikan melalui evaluasi pendidikan atau evaluasi pembelajaran, apakah hasilnya sesuai rencana atau belum ( Check).

d. Memasarkan produk pendidikan dan menyerahkan lulusannya kepada orang tua atau masyarakat, pendidikan lanjut, pemerintah dan dunia usaha (Action).

e. Menganalisis bagaimana produk tersebut diterima dipasar, baik pada pendidikan lanjut ataupun didunia usaha dalam hal kualitas, biaya dan kriteria lainnya (Analyze) ${ }^{37}$

\footnotetext{
${ }^{36} \mathrm{http}: / /$ edukasi.kompasiana.com/2009/12/16/implementasi-manajemen-mututerpadu-total-quality-management-di-sekolah/

37 Bounds, 1994 dalam Mulyadi, Kepemimpinan Kepala Sekolah Dalam Mengembangkan Budaya Mutu, Malang : UIN-MALIKI PREES, 2010, 155.
}

FaLASIFA, Vol. 9 Nomor 1 Maret 2018 | 157 
Goetch dan Davis menyodorkan checklist terkait langkah strategis manajer ( kepala sekolah ) dalam pemgembangan mutu, diantaranya :

a. Identifikasi kebutuhan perubahan

Budaya organisasi saat ini merupakan budaya kualitas jika memenuhi karakteristik berikut :

1) Komunikasi terbuka dan terus menerus.

2) Saling mendukung partnership internal.

3) Menggunakan pendekatan kerja tim dalam menyelesaikan masalah.

4) Berobsesi terhadap perbaikan terus - menerus.

5) Partisipasi dan keterlibatan pekerja secara luas.

6) Memperhatikan masukan dan umpan balik dari konsumen.

b. Menuangkan perubahan yang direncanakan, secara tertulis perubahan yang akan dilakukan harus dibuat daftar disertai penjelasannya.

c. Mengembangkan rencana untuk membuat perubahan

Pengembangan rencana perubahan dapat dilakukan dengan menjawab pertanyaan - pertanyaan who-what-when-where-how, sebagai berikut :

1) Siapa yang kena pengaruh perubahan? Siapa yang harus terlibat agar perubahan berhasil? Siapa yang menentang perubahan?

2) Tugas apa yang harus diselesaikan? Apa saja hambatan utama perubahan? Prosedur dan proses apa yang berhubungan dan kena pengaruh perubahan?

3) Kapan perubahan dilakukan? Kapan kemajuan perubahan diukur? Kapan pelaksanaan perubahan selesai?

4) Di mana dilakukan perubahan? Dimana orang-orang dan proses yang terkena pengaruh perubahan?

5) Bagaimana seharusnya perubahan dibuat? Bagaimar dampak perubahan terhadap orang-orang dan proses yang telah ada? Bagaimana perubahan akan meningkatkan kualitas, produktivitas dan daya saing?

d. Mernahami proses transisi emosi

Pembentukan budaya kualitas termasuk perencanaan dan aktivitas spesifik dalam setiap bisnis dan departemen. Pembentukan budaya kualitas harus diawali dengan memahami proses emosi para pekerja. Manajer perlu untuk mengakui dan mengakomodasi transisi emosi pekerja yang diperlukan tidak hanya pekerja tetapi juga manager itu sendiri sebagai langkah dalam menuju konversi terhadap kualitas. 
e. Identifikasi orang-orang kunci dan membujuk mereka agar mendukung perubahan. ${ }^{38}$

Edward Sallis juga menawarkan terkait konsep mutu untuk diimplementasikan dalam dunia pendidikan, diantaranya :

1) Kepemimpinan dan komitmen terhadap mutu harus datang dari atas

2) Menggembirakan pelanggan adalah tujuan TQM

3) Menunjuk fasilitator mutu

4) Membentuk kelompok pengendalian mutu

5) Menunjuk koordinator mutu

6) Mengadakan seminar manajemen senioruntuk mengevaluasi program

7) Menganalisa dan mendiagnosa situasi yang ada

8) Menggunakan contoh-contoh yang sudah berkembang ditempat lain

9) Memperkerjakan konsultan eksternal

10) Memprakarsai pelatihan mutu bagi para staf

11) Mengkomunikasikan pesan mutu

12) Mengaplikasikan alat dan teknik mutu melalui pengembanga kelompok kerja yang efektif

13) Mengevaluasi program dalam interval yang teratur. ${ }^{39}$

Dari statement TQM diatas, kepemimpinan pendidikan dalam TQM harus mencerminkan : (1) Fokus pada pelanggan, (2) Fokus pada pencegahan masalah, (3) Investasi sumber daya, (4) Memiliki Strategi mutu, (5) Menyikapi komplain sebagai peluang untuk belajar, (6) Mendefinisikan mutu pada seluru area organisasi, (7) Memiliki kebijakan dan rencana mutu, (8) Manajemen senior memimpin mutu, (9) Proses perbaikan mutu melibatkan setiap orang, (10) Memiliki fasilitator mutu yang mendorong kemajuan mutu, (11) Karyawan dianggap memiliki peluang untuk menciptakan mutu, (12) Kreativitas adalah hal yang penting, (13) Memiliki aturan dan tanggung jawab yang jelas, (14) Memiliki strategi evalusi yang jelas, (15) Melihat mutu sebagai sebuah cara untuk meningkatkan kepuasan pelanggan, (16) Rencana jangka panjang, (17) Mutu dipandang sebagai bagian dari budaya, (18) Meningkatkan mutu berada dalam garis strategi imperatif-nya sendiri, (19) Memiliki misi khusus, (20) Memperlakukan kolega sebagai pelanggan

${ }^{38}$ Ibid, 155-159.

39 Edward Sallis, Total Quality Management In Education, Jogjakarta : IRCiSoD, $2010,245-253$.

FaLASIFA, Vol. 9 Nomor 1 Maret 2018 | 159 
Nanang Budianto

\section{KESIMPULAN}

Dari paparan diatas dapat disimpulkan : Kepemimpinan dalam suatu orgasisasi harus bersifat totalitas artinya seorang pemimpin harus memiliki kualitas dan kuantitas dalam mengatur dan menjalankan roda-roda keorganisasiannya. Managemen mutu terpadu ( TQM ) merupakan sebuah konsep mutu untuk melakukan perbaikan secara terus-menerus dan memperhatikan kepuasan pelanggan sehingga tujuan suatu organisasi sesuai tujuan bersama. Kepemimpinan pendidikan perspektif managemen mutu terpadu (TQM) adalah kepemimpinan pendidikan yang mempunyai komitmen untuk peningkatan mutu dan melakuka perbaikan secara terus menerus dalam rangka memenuhi kepuasan pelanggan.

\section{DAFTAR PUSTAKA}

Asmani, Ma'mur, Jamal, Managemen Pengelolaan dan Kepemimpinan Pendidikan Profesional Panduan Quality Kontrol Bagi Para Pelaku Lembaga Pendidikan, Yogyakarta : Diva Pres, 2009.

Bush, Tony dan Marianne Colemen, Manajemen Strategis Kepemimpinan Pendidikan, Jogjakarta : IRCiSoD, 2008.

Burnham, West dalam Tony Bush dan Marianne Colemen, Manajemen Strategis Kepemimpinan Pendidikan, Jogjakarta : IRCiSoD, 2008.

Bounds, 1994 dalam Mulyadi, Kepemimpinan Kepala Sekolah Dalam Mengembangkan Budaya Mutu, Malang : UIN-MALIKI PREES, 2010.

Danim, Sudarwan dan Suparno, Manajemen Dan KepemimpinanTransformasional Kekepala Sekolahan, Jakarta : Reneka Cipta, 2009.

Deming dalam Edward Sallis, Total Quality Management In Education, Jogjakarta : IRCiSoD, 2010.

http://edukasi.kompasiana.com/2009/12/16/implementasi-manajemen-mututerpadu-total -quality-management-di-sekolah/ di akses pada tanggal 17 Agustus 2018

Marno dan Triyo Suprayitno, Managemen dan Kepemimpinan Pendidikan Islam, Bandung : PT. Refika Aditama, 2008.

Mulyadi, Kepemimpinan Kepala Sekolah Dalam Mengembangkan Budaya Mutu, Malang : UIN MALIKI PREES, 2010.

P. Robbins, Stephen, Prilaku Organisasi, Jakarta : PT.Prenhallindo, 2002.

Suprayitno, Triyo, Managemen dan Kepemimpinan Pendidikan Islam, Bandung : PT. Refika Aditama, 2008.

Robbins, P., Stephen, Prilaku Organisasi, Jakarta : PT.Prenhallindo, 2002.

Sergiovanni, 1984, dalam Tony Bush dan Marienne Coleman, Manajemen Strategis Kepemimpinan Pendidikan, (Yogyakarta : IRCiSoD, 2008), hlm 67

Sallis, Edward, Total Quality Management In Education, Jogjakarta : IRCiSoD, 2010 .

160 | FaLASIFA, Vol. 9 Nomor 1 Maret 2018 